\title{
Communication
}

[Comunicação]

\section{Comparison between conventional and computerized electrocardiography in cats}

\author{
[Comparação entre registros eletrocardiográficos convencional e computadorizado em gatos]
}

\author{
A.A. Camacho, D. Paulino Jr., J.P.E. Pascon, A.A. Teixeira
}

Faculdade de Ciências Agrárias e Veterinárias - UNESP

Via de acesso Prof. Paulo Donato Castellane, s/n

14884-900 - Jaboticabal, SP

The electrocardiogram (ECG) provides a representation of the electrical activity of the heart and is a fundamental part of a clinical evaluation. Thus, the ECG is commonly used in small animal practice to diagnose conduction disturbances such as cardiac arrhythmias. These disorders are considerated alterations during the development of the electrical impulse and may occur in face of specific cardiac affectations such as valve, ischemic, or traumatic diseases; cardiomyopathies (Ware and Christensen, 1999); and systemic illness (electrolytic, neurological, and gastrointestinal abnormalities) as well as in patients suffering from systemic infections (Olivier, 1987).

Comparing the conventional $(\mathrm{Cv})$ to the computerized (Cp) ECG method, the second one had shown a higher accuracy, because of its ability to detect readings of 1 millisecond (ms), while in the $\mathrm{Cv}$ method, readings can only be made from $5 \mathrm{~ms}$ in paper speed of $100 \mathrm{~mm} / \mathrm{sec}$ (Schiwen et al., 1996). Also, Cp ECG has some other advantages like the possibility of been used in intensive care units with reliable reproducibility of its measures which enables management of larger volumes of ECGs (Tilley, 1992; Wolf et al., 2000).

The aim of the present study was to analyze the differences in the recorders between conventional and computerized methods (screen monitor and printed recorded data).

Thirty healthy adult cats were housed in appropriate cages, fed a dry pellet diet twice a

Recebido em 24 de março de 2009

Aceito em 30 de abril de 2010

E-mail: camacho@fcav.unesp.br day, and received water ad libitum. The animals were allocated into two groups according to gender: group $\mathrm{F}, \mathrm{n}=16$ females ranging from 2.74 to $4.53 \mathrm{~kg}$ and group $\mathrm{M}, \mathrm{n}=14$ males ranging from 3.57 to $6.10 \mathrm{~kg}$. All animals were submitted to conventional $(\mathrm{Cv})$ and computerized (Cp) electrocardiography. In the $\mathrm{Cv}$ method, a monochannel (ECG6 - ECAFIX) electrocardiographic device, provided with thermal sensitive millimetrated paper was used Fig. 1. For the $\mathrm{Cp}$ electrocardiographic method (EGC-PC version 2.07 - TEB), an electronic circuit connected to a personal computer (Pentium, 1660MHz, 32MB) provided with specific software, able to calculate and analyze electrocardiographic data, was used. Recorded tracings were show on the computer screen Fig.1B. After performing the computerized method, ECG tracings of each subject were printed in order to analyze the recorded data, which was named as computerized printed method (CpP) (Fig.1C). The paper used for printing was endowed with millimetrated spaces for the recording of waves, intervals, and segments defined by the electronic program, by means of a jet printer connected to the computerized ECG.

The animals were positioned on right lateral recumbency, on an appropriate table, with limbs perpendicularly positioned to the trunk. Electrodes were attached to forelimbs and hindlimbs. Speed used for all recordings was $50 \mathrm{~mm} / \mathrm{s}$, with calibration of voltage of 1 centimeter for each millivolt $(1 \mathrm{mV}=1 \mathrm{~cm})$. Both registrations were obtained with a regular sequence, first the $\mathrm{Cv}$ than $\mathrm{Cp}$ method. 


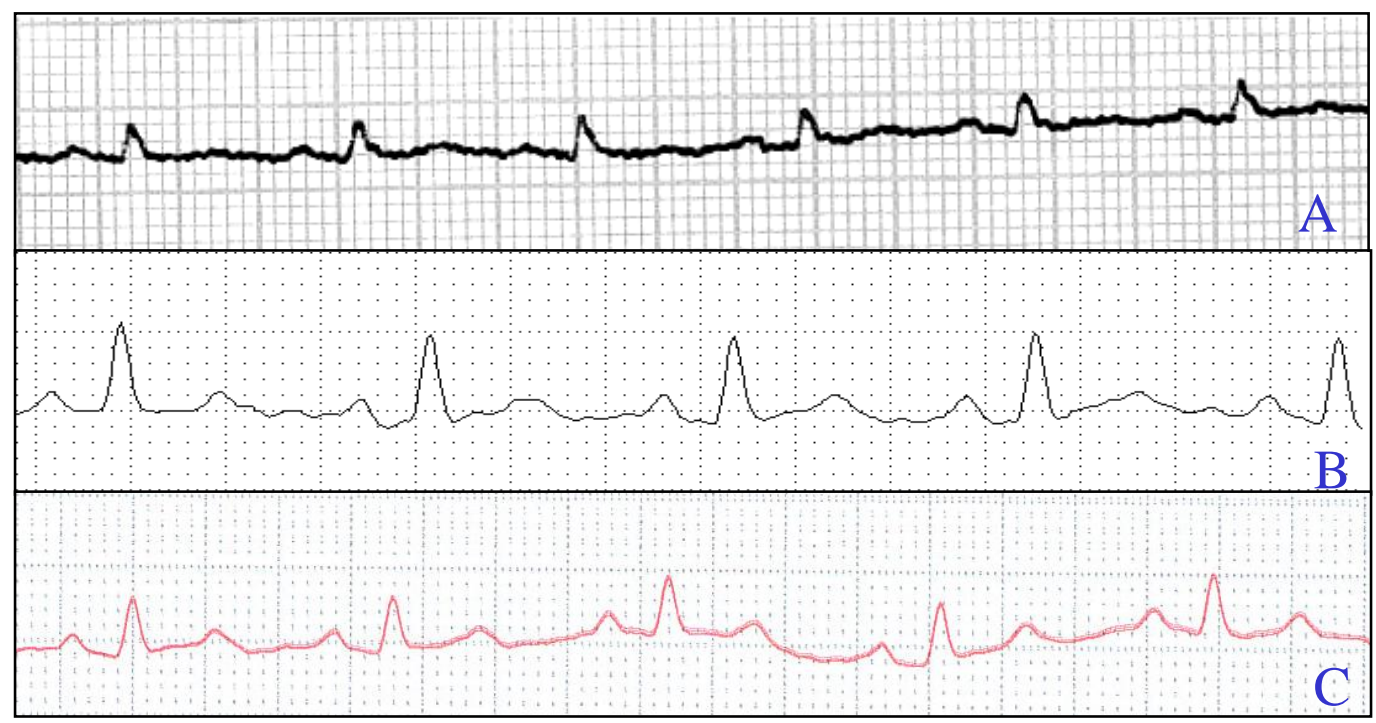

Figure 1. Cat. A: conventional ECG tracing recorded on thermal sensitive paper. B: computerized ECG tracing recorded on the screen monitor. C: computerized ECG tracing printed on paper. A, B, and C recorded in the lead II, at $50 \mathrm{~mm} / \mathrm{s}$ and calibrated to 1 millivolt which corresponds to $1 \mathrm{~cm}$.

The ECGs were recorded in the bipolar lead II (L II) and the evaluated parameters were: heart rate, cardiac rhythm, duration (milliseconds-ms) and amplitude (millivolts-mV) of the $\mathrm{P}$ wave, duration (ms) of the PR, QT interval and QRS complex, amplitude $(\mathrm{mV})$ of the $\mathrm{R}$ wave, polarity characteristics of the $\mathrm{T}$ wave, presence or absence of uneven ST segment, and values (in degrees) of the mean electrical axis (MEA). The electrocardiographic measurements were analyzed in accordance of descriptions made by Tilley (1992).

Data recorded by $\mathrm{Cv}$ and $\mathrm{Cp}$ ECG were analyzed using paired $t$ test in order to interpret possible effects capable to change the means of each variable regarding electrocardiographic methods. Values of $\mathrm{P}<0.05$ were considered significant.

All animals in this study showed a normal cardiac sinus rhythm and absence of wandering pacemaker. Table 1 shows the mean values of $\mathrm{Cv}$ and $\mathrm{Cp}$ ECG. No differences were found in heart rate such as $\mathrm{R}$ wave amplitude between groups. The $\mathrm{P}$ wave duration and amplitude, QRS duration, and the PR and QT intervals were greater $(\mathrm{P}<0.05)$ in both groups by the $\mathrm{Cp}$ ECG. The MEA values were not different between groups $(\mathrm{P}>0.05)$.

Table 1. Means $( \pm$ SEM) of conventional and computerized electrocardiography values in cats, according to gender

\begin{tabular}{llllll}
\hline Group & ECG & HR $(\mathrm{bpm})$ & P Wave $(\mathrm{ms})$ & P Wave $(\mathrm{mV})$ & PR Interval $(\mathrm{ms})$ \\
\hline Female & Cn & $183.75 \pm 32.84$ & $29 \pm 7.15^{*}$ & $0.097 \pm 0.02^{*}$ & $75 \pm 8.16$ \\
$(\mathrm{n}=16)$ & $\mathrm{Cp}$ & $185.75 \pm 27.19$ & $40.87 \pm 3.24$ & $0.12 \pm 0.03$ & $75.62 \pm 13.02$ \\
Male & Cv & $177.14 \pm 28.13$ & $31 \pm 8.10^{*}$ & $0.14 \pm 0.18$ & $69.71 \pm 13.96$ \\
$(\mathrm{n}=14)$ & $\mathrm{Cp}$ & $172.36 \pm 25.35$ & $41.71 \pm 4.03$ & $0.11 \pm 0.02$ & $75.86 \pm 8.83$ \\
Group & ECG & QRS Complex $(\mathrm{ms})$ & R Wave $(\mathrm{mV})$ & QT Interval (ms) & MEA (degrees) \\
Female & Cv & $32.5 \pm 7.28^{*}$ & $0.27 \pm 0.18$ & $136.25 \pm 19.62^{*}$ & $64.31 \pm 52.49$ \\
$(\mathrm{n}=16)$ & $\mathrm{Cp}$ & $43.75 \pm 6.64$ & $0.23 \pm 0.10$ & $155.25 \pm 10.74$ & $68 \pm 46.25$ \\
Male & Cv & $33.57 \pm 7.45^{*}$ & $0.24 \pm 0.14$ & $134.29 \pm 17.85^{*}$ & $55.14 \pm 41.25$ \\
$(\mathrm{n}=16)$ & $\mathrm{Cp}$ & $41.93 \pm 4.71$ & $0.29 \pm 0.19$ & $155.64 \pm 17.08$ & $44.92 \pm 59.09$ \\
\hline
\end{tabular}

HR: heart rate; MEA: mean electrical axis; bpm: beats per minutes; ms: milliseconds; mV: millivolts; Cv: convencional; Cp: computerized. *Different between methods in the same group (paired $t$ test, $\mathrm{P}<0.05$ ). 
The mean values of the $\mathrm{Cv}$ and $\mathrm{CpP}$ methods are showed in Table 2. Heart rate presented similar values between groups and methods $(\mathrm{P}<0.05)$. However, the $\mathrm{P}$ wave duration was greater $(\mathrm{P}<0.05)$ in Group $\mathrm{F}$ by the $\mathrm{CpP}$ method compared to $\mathrm{Cv}$. Group $\mathrm{M}$ presented greater $\mathrm{P}$ wave amplitude in the $\mathrm{Cv}$ ECG compared to $\mathrm{CpP}$. No differences were found in PR duration, QRS, and QT intervals, as well as the MEA.

Table 2. Means $( \pm$ SEM) of conventional and computerized P (printed recorded data) electrocardiographic values in cats, according to gender

\begin{tabular}{llcccc}
\hline Group & ECG & HR $(\mathrm{bpm})$ & P Wave $(\mathrm{ms})$ & P Wave $(\mathrm{mV})$ & \multicolumn{1}{c}{ R Interval (ms) } \\
\hline Female & $\mathrm{Cv}$ & $183.75 \pm 32.84$ & $29 \pm 7.15^{*}$ & $0.097 \pm 0.02$ & $75 \pm 8.16$ \\
$(\mathrm{n}=16)$ & $\mathrm{CpP}$ & $185 \pm 25.82$ & $37.62 \pm 4.53$ & $0.11 \pm 0.02$ & $77.5 \pm 17.70$ \\
Male & $\mathrm{Cv}$ & $177.14 \pm 28.13$ & $31 \pm 8.10 \mathrm{NS}$ & $0.14 \pm 0.18^{*}$ & $69.71 \pm 13.96$ \\
$(\mathrm{n}=14)$ & $\mathrm{CpP}$ & $172.86 \pm 24.31$ & $36.43 \pm 6.17$ & $0.10 \pm 0.02$ & $72.43 \pm 8.56$ \\
Group & $\mathrm{ECG}$ & QRS Complex$(\mathrm{ms})$ & $\mathrm{RWave}(\mathrm{mV})$ & QTInterval(ms) & MEA(degrees) \\
Female & $\mathrm{Cv}$ & $32.5 \pm 7.28$ & $0.27 \pm 0.18$ & $136.25 \pm 19.62$ & $64.31 \pm 52.49$ \\
$(\mathrm{n}=16)$ & $\mathrm{CpP}$ & $37.37 \pm 7.15$ & $0.23 \pm 0.11$ & $146.50 \pm 14.65$ & $65.12 \pm 47.40$ \\
Male & $\mathrm{Cv}$ & $33.57 \pm 7.45$ & $0.24 \pm 0.14$ & $134.29 \pm 17.85$ & $55.14 \pm 41.25$ \\
$(\mathrm{n}=14)$ & $\mathrm{CpP}$ & $37.71 \pm 4.08$ & $0.29 \pm 0.21$ & $148.57 \pm 20.70$ & $43.78 \pm 58.44$ \\
\hline
\end{tabular}

HR: heart rate; MEA: mean electrical axis; bpm: beats per minutes; ms: milliseconds; mV: millivolts; Cv: conventional; CpP: computerized P. *Different between methods in the same group (Paired $t$ test $-\mathrm{P}<0.05$ ).

Table 3 shows the mean values of $\mathrm{Cp}$ and $\mathrm{CpP}$ ECG for both groups ( $M$ and $F$ ). No differences were observed in the heart rate, $\mathrm{P}$ and $\mathrm{R}$ waves amplitudes, and PR and QT intervals. Both groups presented $\mathrm{P}$ wave and QRS complex duration greater $(\mathrm{P}<0.05)$ by $\mathrm{Cp}$ method. The MEA did not differ between groups.

Table 3. Means $( \pm$ SEM) of computerized and computerized $\mathrm{P}$ (printed recorded data) electrocardiographic values in cats, according to gender

\begin{tabular}{clllll} 
Group & ECG & HR $(\mathrm{bpm})$ & P Wave $(\mathrm{ms})$ & P Wave $(\mathrm{mV})$ & PR Interval (ms) \\
\hline Female & Cp. & $185.75 \pm 27.19$ & $40.87 \pm 3.24^{*}$ & $0.12 \pm 0.03$ & $75.62 \pm 13.02$ \\
$(\mathrm{n}=16)$ & CpP & $185 \pm 25.82$ & $37.62 \pm 4.53$ & $0.11 \pm 0.02$ & $77.5 \pm 17.70$ \\
Male & Cp. & $172.36 \pm 25.35$ & $41.71 \pm 4.0^{*}$ & $0.11 \pm 0.02$ & $75.86 \pm 8.83$ \\
$(\mathrm{n}=16)$ & CpP & $172.86 \pm 24.31$ & $36.43 \pm 6.17$ & $0.10 \pm 0.02$ & $72.43 \pm 8.56$ \\
Group & ECG & QRS Complex $(\mathrm{ms})$ & R Wave $(\mathrm{mV})$ & QT Interval $(\mathrm{ms})$ & MEA (degrees) \\
Female & Cp & $43.75 \pm 6.64^{*}$ & $0.23 \pm 0.10$ & $155.25 \pm 10.74$ & $68 \pm 46.25$ \\
$(\mathrm{n}=16)$ & CpP & $37.37 \pm 7.15$ & $0.23 \pm 0.11$ & $146.50 \pm 14.65$ & $65.12 \pm 47.40$ \\
Male & Cp & $41.93 \pm 4.71^{*}$ & $0.29 \pm 0.19$ & $155.64 \pm 17.08$ & $44.92 \pm 59.09$ \\
$(\mathrm{n}=16)$ & CpP & $37.71 \pm 4.08$ & $0.29 \pm 0.21$ & $148.57 \pm 20.70$ & $43.78 \pm 58.44$ \\
\hline
\end{tabular}

HR: heart rate; MEA: mean electrical axis; bpm: beats per minutes; ms: milliseconds; $\mathrm{mV}$ : millivolts; $\mathrm{Cp}$ : computerized; CpP: computerized P. *Different between methods in the same group (paired $t$ test $-\mathrm{P}<0.05$ ).

Considering the $\mathrm{T}$ wave polarity, similar values of positive and biphasic waves for Group F were observed in all methods. Negative waves were not observed in Group F. Controversially, a great percentage of positive waves compared to the biphasic waves were observed in Group F. Group $M$ presented similar values for positive and biphasic waves in $\mathrm{Cp}$ and $\mathrm{CpP}$ methods. A great percentage of positive waves were observed in this group (Table 4).

Conventional ECG is a non invasive and feasible diagnostic method commonly used in veterinary medicine to access alterations in the cardiac rhythm, as well as baseline values of intervals, segments, amplitudes, and wave durations (Hoffman and Cranefield, 1964; Tilley, 1992). However, there is a requirement for more studies to obtain references values from the computerized ECG method in cats. The comparison of results from the three different methods ( $\mathrm{Cv}, \mathrm{Cp}, \mathrm{Cp} \mathrm{P})$, highlighted that the $\mathrm{P}$ wave duration (ms) and QRS complex (ms), in both groups ( $\mathrm{F}$ and $\mathrm{M})$, featured significant increased values for the $\mathrm{Cp}$ and $\mathrm{CpP}$ methods with regard to $\mathrm{Cv}$ method (Tilley, 1992). Results in dogs were reported in a previous study, when the $\mathrm{Cv}, \mathrm{Cp}$, and $\mathrm{CpP}$ methods were compared (Wolf et al., 2000). 
Table 4. Percentage of occurrence of the $\mathrm{T}$ wave in accordance to its polarity in cats submitted to conventional, computerized (monitor screen), and computerized P (printed recorded data) ECGs, according to gender

\begin{tabular}{lccccccccc}
\hline \multirow{2}{*}{ Group } & \multicolumn{3}{c}{ Convencional ECG } & \multicolumn{3}{c}{ Computerized ECG } & \multicolumn{3}{c}{ Computerized P ECG } \\
\cline { 2 - 10 } & \multicolumn{3}{c}{ Polarity of the T wave } & \multicolumn{3}{c}{ Polarity of the T wave } & \multicolumn{3}{c}{ Polarity of the T wave } \\
\cline { 2 - 10 } & Pos & Neg & Biph & Pos & Neg & Biph & Pos & Neg & Biph \\
\hline $\begin{array}{l}\text { Female } \\
(\mathrm{n}=16)\end{array}$ & 87.50 & 0 & 12.50 & 87.50 & 0 & 12.50 & 87.50 & 0 & 12.50 \\
$\begin{array}{l}\text { Male } \\
(\mathrm{n}=14)\end{array}$ & 71.44 & 14.28 & 14.28 & 85.72 & 0 & 14.28 & 85.72 & 0 & 14.28 \\
\hline
\end{tabular}

Pos: positive; Neg: negative; Biph: biphasic.

Other variables significantly changed when comparing the three different ECG methods, notably the $\mathrm{P}$ wave amplitude $(\mathrm{mV})$, duration of the QT interval, and polarity of the $\mathrm{T}$ wave, nevertheless these results did not exceed the values preconized for the $\mathrm{Cv}$ method, which was also seen in another study with dogs (Wolf et al., 2000).

In the meantime, significant differences were not evidenced in some variables, such as duration of the PR interval (ms), $R$ wave amplitude $(\mathrm{mV})$, unlevelling of the ST segment, and MEA, in contrast with another study that reported these differences in dogs (Wolf et al., 2000).

Notwithstanding, the cardiac rhythm did not vary between the various ECG methods used in this study, been characterized as $100 \%$ sinus rhythm, in accordance with other authors, which verified rhythm constancy, independently of the method used, with the exception of respiratory sinus arrhythmia in all groups of dogs (Wolf et al., 2000). Such difference may be explained due to the higher activity of the sympathetic autonomous component present in the feline species when comparing with the canine, which more often shows enhanced of the parasympathetic tonus (Tilley, 1992; Kittleson, 1998).

The differences between the $\mathrm{Cv}$ and $\mathrm{Cp}$ methods seen in this study may be attributed to the higher accuracy of the computerized measurement because, according to Shiwen et al. (1996), this method is able to detect readings of $1 \mathrm{~ms}$, whereas the $\mathrm{Cv}$ method, the reading can only be made from $5 \mathrm{~ms}$, with paper speed of $100 \mathrm{~mm} / \mathrm{sec}$. Moreover, it was noticed that the Cp ECG method allows monitoring for longer period, which ultimately makes it a value alternative in intensive care units and it confers the capacity of managing and storing larges volumes of electrocardiograms in a shorter period. In addition, it enables the concomitant observation of several leads, beyond an easier and faster method to measure waves and intervals (Tilley, 1992; Nunes, 2002). Furthermore, depending of the operational system, the informatized method shows reproducibility of its measurements, improves the control of quality, and allows comparisons between electrocardiographic tracings obtained in different periods.

In conclusion, this study ensures that there are differences among the three ECG methods herein evaluated, notably the computerized method, which showed mean values of duration of the $\mathrm{P}$ wave and QRS complex above the reference values preconized for the conventional method. Considering these differences, special attention should be given during the computerized electrocardiographic interpretation in both clinically healthy cats and those suffering from any cardiac disease.

Keywords: feline, electrocardiogram

\section{RESUMO}

Foram analisados e comparados, os registros eletrocardiográficos (ECG) obtidos pelos métodos convencional $(\mathrm{Cv})$, computadorizado (Cp) e pela leitura direta do registro computadorizado impresso (CpP) de 30 gatos adultos sem raça definida, clinicamente normais e distribuídos em dois grupos: grupo $F$ ( $n=16$ fêmeas) $e$ grupo $M(n=14$ machos). Para a análise estatística, utilizou-se o teste t. Não foi observada diferença entre os grupos. Entre os métodos, foram observadas diferenças quanto à duração em milissegundos da onda $P$ e do complexo QRS, especialmente em relação ao método computadorizado.

Palavras-chave: felino, eletrocardiograma 
The authors would like to thank FAPESP for supporting this project.

\section{REFERENCES}

HOFFMAN, B.F.; CRANEFIELD, P.F. The physiological basis of cardiac arrhythmias. Am. J. Med., v.37, p.670-684, 1964.

KITTLESON, M.D. Diagnosis and treatment of arrhythmias (dysrhythmias). In: KITTLESON, M.D.; KIENLE, R.D. (Eds). Small animal cardiovascular medicine. St. Louis: Mosby, 1998. p.449-494.

NUNES, N. Monitoração da anestesia. In: FANTONI, D.T.; CORTOPASI, S.R.G (Eds). Anestesia em cães e gatos. São Paulo: Roca, 2002. p.15-22.
OLIVIER, N.B. Therapy antiarrhythmic. In: BONAGURA J.D. (Ed). Cardiology. New York: Churchil Livingstone, 1987. p.219-249.

SCHIWEN, Y.; WOHLFART, B.; OLSSON, S.B. et al. Clinical application of a microcomputer system for analysis of monophasic action potentials. PACE, v.19, p.297-308, 1996.

TILLEY, L.P. Essentials of canine and feline electrocardiography. 3.ed. Philadelphia: Lea \& Febiger, 1992. 470p.

WARE, W.; CHRISTENSEN, W.F. Duration of the QT interval in healthy cats. Am. J. Vet. Res., v.60, p.1426-1429, 1999.

WOLF, R.; CAMACHO, A.A.; SOUZA, R.C.A. Eletrocardiografia computadorizada em cães. Arq. Bras. Med. Vet. Zootec., v.52, p.610-615, 2000. 